\title{
Metaphoric Perceptions of Adolescents towards the Concept of Corona Virus (COVID-19)
}

\author{
Fatih Aydoğdu \\ Health Services Vocational School, Department of Child Development, Erzincan Binali Yıldırım \\ University, Erzincan, Turkey \\ faydogdu1985@gmail.com
}

Figen Gürsoy

Faculty of Health Science, Department of Child Development, Ankara University, Ankara, Turkey

\begin{abstract}
This research was carried out to examine the metaphoric perceptions of adolescents regarding the concept of coronavirus (COVID-19).For this purpose, 60 adolescents (33 girls, 27 boys) studying at different grade levels of three high schools at different socio-economic levels determined by maximum diversity sampling from high schools in Erzincan city center were included in the research.With the questionnaireform developed for adolescents, "Coronavirus (COVID-19) ......is similar. Because........" was asked.The data obtained were analyzed by content analysis method. In this context, categories suitable for metaphors were created and the consistency of the categories with metaphors and descriptions was determined. Eight metaphors that are not suitable for the subject of the study are excluded from the study. In line with the results obtained, it was determined that adolescents developed 49 different metaphors and these metaphors were collected under eight categories. It can be said that the metaphoric perceptions of adolescents regarding the concept of coronavirus (COVID-19) are generally negative.
\end{abstract}

Keywords:Adolescent, metaphor, metaphoric perception, pandemic, corona virus (COVID-19)

\section{Introduction}

Diseases adversely affect growth and development. Especially acute and chronic infectious diseases affect the individual in terms of nutrition, physical functionality, mental health and intellectually (Reiner et al., 2019). Infectious diseases such as chronic hepatitis, HIV and other sexually transmitted infections also cause millions of individuals to have health problems (Khabbaz et al., 2014). One of the infectious diseases is the new type of coronavirus, which emerged as the epidemic of the century.

The coronaviruses that infect humans, but also infect a large number of animals, have enveloped, positive single-stranded large RNA, are transmitted from animals to humans in China's Huanan seafood market in Wuhan. Later, the COVID-19 outbreak entered a new phase that is spreading rapidly in countries outside China. Outbreak cases have been confirmed in 210 countries or regions as of April 11, 2020. (Dsouza et al., 2020). The economic and psychosocial consequences of the COVID-19 epidemic have been wide-ranging and unprecedented worldwide (Pakpour and Griffiths, 2020). In all societies where the epidemic is effective, people have begun to take measures to protect themselves and prevent the infection from spreading to others (Bedford et al., 2020). 
Pandemias are not just a medical phenomenon; they affect individuals and society at many levels and cause problems (Jiloha, 2020). Corona virus affects individuals at any age. Although this epidemic is more effective on adults and the elderly, children are also in an important risk group. Children of all ages and all countries, especially the ones in the socioeconomically disadvantaged groups, are more affected by the outbreak. Even if children do not get the disease, the loss of a relative due to the epidemic, socio-economic effects and measures taken to stop the epidemic may have a negative effect on children (Cullinane and Montacute, 2020).

It has been forbidden since April 32020 for the individuals under the age of 20 to go out to prevent the outbreak in Turkey. Although these measures and efforts are highly commendable and necessary, the fact that schools are closed for a long time and children cannot go out during an epidemic can have negative effects on children's physical and mental health. Being under quarantine at home can put more psychological burden than physical pain caused by the virus. When children do not go to school, they become less physically active, stay dependent on the screen for longer, sleeping and eating habits are changing, and this can cause weight gain and cardiovascular diseases. In addition, the negative effects of the epidemic on health increase since children cannot perform outdoor activities and cannot spend time with their peers (Wang et al., 2020). In a study involving 2111 people aged 25 and under in the UK, 83\% of respondents stated that the outbreak even more worsened the conditions (Lee, 2020). It is also stated that isolation and quarantine can lead to symptoms such as depression, anxiety, sleep disturbance, panic, phobia, trauma (Hawryluck et al., 2004; Jiloha, 2020; Shaw, 2020).

Because of the epidemic, stressful situations such as long-term fear of infection, frustration, insufficient information, lack of face-to-face contact with classmates and teachers, lack of personal space at home and loss of family finances may have even more problematic and permanent effects on adolescents. At this point, parents are important role models. In long-term isolation, parents can relieve children through close and open communication with them. The epidemic can even be turned into an advantage with parental support.During the quarantine process, family members get the opportunity to get to know each other more closely. Thanks to the interactions they have with each other. They gain responsibility awareness by sharing household chores within the home. Children comprehend better the importance of school, friends and social life.

Taking steps to promote healthy practices and protect young people better from health risks during adolescence is critical for preventing health problems and for the future health and social infrastructure of countries (Taghizadeh et al., 2016).In this context, researching the effects of the COVID-19 pandemic on adolescents can contribute to practices in improving the health of adolescents. Some studies have been conducted on the effect of the new type of coronavirus epidemic on adolescents.In these studies, the effects of the pandemic on the general mental health of adolescents (Cao et al., 2020; Golberstein, Wen, \& Miller, 2020), the effect of school closure on nutritional problems (Davis et al., 2020; Rundle et al., 2020), and the psychological needs of adolescents (Jiao et al., 2020), the psychological effects of school closure (Lee, 2020), the relationship between school closure and child poverty (Van Lancker \& Parolin, 2020), mental problems of quarantined children (Liu et al., 2020; Wang et al. et al., 2020) have been researched.Research results have shown that the epidemic has significant effects on adolescents. Therefore, determining the perception of adolescents about the concept of coronavirus, which is a new epidemic, can be a source for the studies to determine the effect of the epidemic on adolescents and to eliminate negative effects on adolescents. In addition, the study will be able to 
form an idea about what effects epidemics may have on adolescents in the future, and will be able to lay the groundwork for the applications to protect the mental health of adolescents in case of an outbreak. As the coronavirus epidemic has started to spread in many countries, especially in China, it is seen that the studies are mostly done in these countries. In Turkey, there are limited studies to determine the effect of the outbreak on adolescents due to some reasons such as the later emergence of the outbreak and the difficulty in performing application on adolescents (Görgülü Arı and Arslan, 2020; Şahbudak and Inal Emiroğlu, 2020). In addition, no study about determining the metaphoric perceptions of adolescents (high school level) regarding the concept of coronavirus (COVID-19) has been found. In this context, it was aimed to examine the metaphoric perceptions of adolescents studying at high school level regarding the concept of "coronavirus (COVID-19)".

\subsection{Research Questions}

1. What are the metaphors that adolescents produce regarding the concept of coronavirus (COVID-19)?

2. Under which categories are the metaphors produced by adolescents regarding the concept of coronavirus (COVID-19)?

\section{Method}

In this part of the research, topics such as the research model, working group, data collection tools, collection of data and data analysis are included.

\subsection{Research Design}

In this research, the phenomenology pattern, which is one of the qualitative research patterns, was used. The phenomenology pattern focuses on the cases that we are aware of but do not have an in-depth and detailed understanding. Phenomenological research differs from other qualitative research patterns in that it tries to understand the essence of a phenomenon for participants who experience it (Christensen, Johnson and Turner, 2011). Since the phenomenological researches commonly used in social sciences (Qutoshi, 2018) are related to the experience of the individual (Tut, Kıroğlu and Bayraktar, 2018), the special experiences of the participants are dealt with in such researches and their perceptions and the meaning they attribute to the events are examined (Ekici and Akdeniz, 2018).

\subsection{Participants}

In the research, maximum diversity sampling, which is one of the purposeful sampling methods, is used to determine the study group. In this sampling method, whether there are common or shared cases among the diverse situations and different dimensions of the problem according to this diversity are examined (Marczyk and DeMatteo, 2005). Maximum diversity sampling is used to determine the discrepancy at the far ends of a range, to select heterogeneous samples or to achieve the representativeness of the purpose (Gentles et al., 2015). Since this study aims to collect more information by selecting heterogeneous samples, 60 adolescents studying in the different classes of three different socioeconomic high schools in Erzincan city center were included in the research. 55\% (33) of the participants are girls, 30\% (18) are in 12th grade (9th grade: 12th, 10th grade: 14th, 11th grade: 16), 65\% (39) have two or fewer siblings (three or more siblings: 21 ), the mothers of $70 \%$ (42) have a secondary education level and below (high school and above: 18), the fathers of $56.7 \%$ (34) have a secondary education level and below (high school and above: 26). In addition, $88.3 \%$ (50) of adolescents stated that there was no relative who suffered from the coronavirus epidemic. 


\subsection{Data Collection Instruments}

"Personal Information Form" and "Questionnaire Form" were used in the study to obtain data. In the personal information form, there are questions about gender, grade level, number of siblings, parental education status and questions about determining whether someone near them has a coronavirus outbreak. In the questionnaire form, there were questions to determine their feelings about epidemic and how it affects their lives as well as the question "The Coronavirus (COVID19) is similar to

\subsection{Data Collection Process}

First of all, the study was approved by the Erzincan Binali Yıldırım University Humanitarian Research Ethics Committee (Protocol No:04/05, Date: 30/04/2020). Afterwards, permission was obtained from the Erzincan Provincial Directorate of National Education, and the school administrators were interviewed to apply to children studying in three high schools with different socioeconomic backgrounds. A form was sent via Google form to children from all grade levels who volunteered to participate in the study and whose consent was given by their families.Volunteer approval was requested in the form regarding the participation of children in the research. The children were informed about how to fill out the form, and the families were asked to guide their children by filling in the form without anyone's intervention.

\section{Data Analysis}

Since content analysis was carried out in order to make the analyzes that could reveal the meanings in the studies conducted in the phenomenology pattern (Y1ldırım \& Şimşek, 2016), the content analysis method was used to analyze the data. The main purpose of content analysis is to reach concepts and relationships that can explain the collected data. Accordingly, 60 forms obtained from adolescents were examined one by one, and the subject of metaphor, source of metaphor and the relationship between them were reviewed. Eight forms (wedding hurry, simple disease, year of 2020, wave, black cloud, evil of natüre, lie, family) that are not suitable for this purpose was excluded from evaluation. For example, some inappriopriate statements such as "It is similar to a wedding hurry. Because let's get through the wedding as soon as possible." were removed. The metaphors were then combined under certain categories, taking into account the features emphasized by the explanations, the similarities and differences in the meanings attributed to the metaphors. In this context, the metaphors are categorized under eight categories: infectious-common, anxious-frightening, restrictive, boring, similarity, instructive, struggle against difficulties and strong. Afterwards, the list with the descriptions of the categories and metaphors was presented to two experts to get their opinion. In line with the feedback of the experts, the Huberman formula (1994) (Reliability = Consensus / [Consensus + Disagreement] * 100) was used to determine consensus and differences between the opinions of the experts'. The consistency between the opinions of experts and researchers was determined as 94\%. This value is considered to be reliable because it is higher than 90\% (Saban, 2004). While reporting the research, metaphors and categories were tabulated and frequency and percentage calculations were made. In addition, the validity of the research was increased by making direct quotations from the participants' opinions.

\section{Results}

The metaphors obtained from the analysis of the data in the research and the categories of metaphors are presented below. 
Metaphors developed by adolescents about the concept of coronavirus (COVID-19) are shown in Table 1.

Table 1. Adolescents' metaphors about the concept of coronavirus (COVID-19)

\begin{tabular}{llllll}
\hline $\begin{array}{l}\text { Metaphor } \\
\text { Code }\end{array}$ & Metaphor Name & f & $\begin{array}{l}\text { Metaphor } \\
\text { Code }\end{array}$ & Metaphor Name & f \\
\hline 1 & School & 2 & 26 & Alcohol & 1 \\
\hline 2 & Prison & 2 & 27 & Fume & 1 \\
\hline 3 & Cage & 2 & 28 & School Hour & 1 \\
\hline 4 & Film & 1 & 29 & Horror Film & 1 \\
\hline 5 & Battle & 1 & 30 & Sea & 1 \\
\hline 6 & Serial Killer & 1 & 31 & Sticky & 1 \\
\hline 7 & Killer & 1 & 32 & Guilty & 1 \\
\hline 8 & Enemy & 1 & 33 & Bad Human & 1 \\
\hline 10 & Spanish Flu & 1 & 34 & Dust Particle & 1 \\
\hline 11 & White Light & 1 & 35 & Life & 1 \\
\hline 12 & Death & 1 & 36 & Gum & 1 \\
\hline 13 & Teacher & 1 & 37 & Message & 1 \\
\hline 14 & Authoritarianism & 1 & 38 & Punishment & 1 \\
\hline 15 & Invisible Enemy & 1 & 39 & Level Up In Game & 1 \\
\hline 16 & Gem & 1 & 40 & Fire & 1 \\
\hline 18 & Course Hour & 1 & 41 & Dye & 1 \\
\hline 19 & Bad Friend & 1 & 42 & Windowless House & 1 \\
\hline 20 & Monster & 1 & 43 & Bomb & 1 \\
\hline 21 & Natural Disaster & 1 & 44 & Slug & 1 \\
\hline 23 & My Old Lover & 1 & 45 & Exam Period & 1 \\
\hline 25 & Flu & 1 & 46 & Diet & Influenza \\
\hline
\end{tabular}

When Table 1 is examined, it is seen that adolescents produce 49 different metaphors related to the concept of coronavirus (COVID-19). Sample statements about the metaphors produced by adolescents are given below:

Exam period: This virus makes me to want to get rid of it as soon as possible and go out and wander. Because I'm stressed and restless in both cases. I can't go out because of the virüs because I don't want to be infected and contaminate to others. I have to work during the exam period, or I can damage my future.

Alcohol: When someone gets into a habit of alcohol, they gradually encourage people around them and damage their body slowly.

Natural disaster: A natural disaster is capable of affecting the whole world. At the same time, it is like a natural disaster that puts human beings in a great stultify, causes great destruction worldwide, and requires a long process to return to the old order.

Spanish flu: It may have occurred in China, but since it is very common in Europe, and other diseases are also common there, it is similar to those diseases. 
Film: With its multiple scenarios, I think it teaches life, living, breathing, and even a hug is very valuable.

Level up in the game: If you can't level up, you will die. If you level up, you win. Likewise, if you beat the virus, you will survive. So you level up and become immune to that virus. If you can't beat the virus, you will die.

School time: As in the virus, lessons are requested to be completed immediately at school. freedom.

Contaminated toy: You can not play freely with a dirty toy. This situation restricts your

Guilty: It is outside and we humans are anxious that it is out and we don't want to go out; we want it to be caught and imprisoned immediately so that we will have a safe life.

Slug: Once it smears, it does not leave. It visits our family.

Horror film: I close my eyes and wait for the horror scene to pass and the film ends soon. Because we expect this virus to pass as soon as possible, and with a happy end, our fear will end and the virus will go away.

The categories of metaphors developed by adolescents about the concept of coronavirus (COVID-19) are shown in Table 2.

Table 2. The categories of metaphors developed by adolescents about the concept of coronavirus (COVID-19)

\begin{tabular}{|c|c|c|c|c|}
\hline Category & Metaphors & $\begin{array}{l}\text { Number of } \\
\text { metaphors }\end{array}$ & $\mathbf{f}$ & $\%$ \\
\hline $\begin{array}{l}\text { Infectious- } \\
\text { common }\end{array}$ & $\begin{array}{l}\text { Alcohol (1), dye (1), smoke (1), flu (1), sticky (1), dust } \\
\text { granule (1), enemy (1), bad person (1), sea (1), gum (1) }\end{array}$ & 10 & 10 & 19.2 \\
\hline $\begin{array}{l}\text { Anxious- } \\
\text { frightening }\end{array}$ & $\begin{array}{l}\text { Exam period (1), sneaky enemy (1), invisible enemy (1), } \\
\text { death (1), lice (1), killer (1), serial killer (1), criminal (1), } \\
\text { horror movie (1) }\end{array}$ & 9 & 9 & 17.3 \\
\hline Restrictive & $\begin{array}{l}\text { Prison (2), cage (2), martial law (1), school (1), prison } \\
(1) \text {, diet (1), contaminated toy (1) }\end{array}$ & 7 & 9 & 17.3 \\
\hline Boring & $\begin{array}{l}\text { School (1), school hour (1), class hour (1), bad friend (1), } \\
\text { windowless house (1), house penalty (1) }\end{array}$ & 6 & 6 & 11.5 \\
\hline Similarity & $\begin{array}{l}\text { Tuberculosis (1), Spanish flu (1), flu infection (1), slug } \\
\text { (1), ex-lover (1) }\end{array}$ & 5 & 5 & 9.6 \\
\hline Instructive & $\begin{array}{l}\text { Message (1), movie (1), white light (1), teacher (1), } \\
\text { punishment (1) }\end{array}$ & 5 & 5 & 9.6 \\
\hline $\begin{array}{l}\text { Struggle } \\
\text { against } \\
\text { difficulties }\end{array}$ & Life (1), leveling up in the game (1), war (1), match (1) & 4 & 4 & 7.7 \\
\hline Strong & Monster (1), bomb (1), natural disaster (1), fire (1) & 4 & 4 & 7.7 \\
\hline TOTAL & & 49 & 52 & 100 \\
\hline
\end{tabular}

As can be seen in Table 2, the metaphors developed by adolescents about the concept of coronavirus (COVID-19) are gathered under eight categories. These are determined as infectious-common (19.2\%), anxious-frightening (17.3\%), restrictive $(17.3 \%)$, boring $(11.5 \%)$, similarity $(9.6 \%)$, instructive $(9.6 \%)$, struggle against difficulties $(7.7 \%)$ and strong $(7.7 \%)$. 


\section{Discussion}

The coronavirus (COVID-19) outbreak is being tackled all over the world. This struggle is not only limited with the improvement of health conditions, but also studies in education, economic, social and psychological fields are carried out. While these studies are carried out to prevent the increase of the epidemic, they also contribute to reducing the psychological effect of the epidemic on individuals; because even if the epidemic disappears, psychological effects of it can last for many years. This effect may be more especially in adolescent children who are sensitive and have social-emotional changes. In this regard, the metaphoric perceptions of adolescents regarding the concept of coronavirus (COVID-19) were examined and the perceptions it formed in children were revealed.

According to the results obtained from the study, 52 adolescents included in the study produced 49 different metaphors related to the concept of coronavirus (COVID-19). These metaphors are categorized under eight categories: infectious-widespread, anxious-frightening, restrictive, boring, similarity, instructive, struggling against difficulties and strong. When the categories are examined, it is seen that adolescents combine the concept of coronavirus (COVID19) in many different categories. However, it can be said that the majority of adolescents perceive the concept negatively. Adolescents' perception of this concept in the infectiouswidespread category can be explained by the epidemic being infectious and seen all over the world; in the anxiety-frightening category can be explained by causing illness and dragging it to health problems and death; in the restrictive and boring category can be explained by the fact that adolescents are under quarantine and their social activities are limited; similarity can be explained by similar outbreaks in the world before; in the tutorial category can be explained by giving an idea about what to do to prevent the outbreak; and in the strong category can be explained by the fact that it is spoken within the family and that it is widespread throughout the world. Görgülü Arı and Arslan (2020), in a similar place with secondary school, used metaphors for Covid-19 with "Contagiousness", "Fatal", "Disease-Causing", "Distancing from Social Environments", "Late Noticed" and "Other Diseases They have revealed that "Relationship" merged under categories.

The COVID-19 outbreak has also caused a parallel outbreak of fear, anxiety, and depression (Yao, Chen and $\mathrm{Xu}, 2020$ ). These problems, which negatively affect mental health, may have deeper effects on adolescents who are sensitive especially in the period they are in. Even if the adolescents or their families do not suffer from epidemic disease, the mental health of adolescents may be adversely affected because of the fact that they are immediately put into quarantine practices, there are conflicts within the family, restricted from their social activities, their education is interrupted, the news in social media about the epidemic in the country and in the world, and the epidemic is spoken in the family. Sprang and Silman (2013) found that 30\% of children who were quarantined and isolated as a result of a pandemic disaster had posttraumatic stress disorder. In addition, adolescents with low socio-economic levels may have produced more negative metaphors, since the study group was chosen from low, medium and high socio-economic schools. Because adolescents and their families with low socio-economic level may experience more economic difficulties with the effect of quarantine. Besides, it seems difficult for children from low-income households to complete homework and online courses due to their insecure housing (Van Lancker and Parolin, 2020). Adolescents who do not have a computer and internet connection to continue their education through distance education may have problems. This problem will widen the gap between the children of low-income families and their peers. This situation may adversely affect children's mental health. 
Adolescents who are in quarantine during the epidemic may be more affected by the family because they spend all days at home. Behavior of families towards the epidemic can have a significant impact on children. The fact that adults are interested in the consequences of COVID-19 can jeopardize children's ability to recognize and respond to their emotions precisely (Stein et al., 2009). This situation can prevent children from sharing their feelings. However, children want to receive descriptive and accurate information about the outbreak from their families. Without this information, children try to understand the situation by themselves (Christ and Christ, 2006). Anxiety and stress can arise when children do not understand what is happening and do not share their feelings. Another factor by which adolescents are most affected in quarantine is the news in social media. Sudden and constantly published news reports about an epidemic can cause everyone to feel worried and anxious. (Jiloha, 2020).

It has been determined that some of the metaphors (17.3\%) produced by adolescents are in positive categories such as instructive and struggling with difficulties. Although there are many negative aspects of the epidemic, due to the epidemic, adolescents have formed an opinion about what should be considered to be protected from the epidemic or diseases. Adolescents can also get awareness about combating difficulties by taking precautions to avoid the epidemic (such as being isolated, taking care of cleanliness). Staying in quarantine can offer a good opportunity to improve interaction between parents and children, involve children in family activities and develop self-sufficiency skills (Perrin, 2020).

\section{Conclusion}

Adolescents produced 49 different metaphors for the concept of coronavirus (COVID19).Metaphors were collected in eight categories as contagious-common, anxiety-frightening, restrictive, boring, similarity, instructive, struggle against difficulties and strong. The results show that adolescents have different perceptions of the concept of corona virus and generally have negative perceptions.

\section{Recommendations}

In line with the findings obtained from this research, we propose the following:

- Schools should not be limited to implementing curriculum programs for children only through distance education, instead, teachers should work on communicating effectively with children and providing psychological support.

- Families should communicate openly and closely with the child, it should be stated that the epidemic is not the result of their previous behaviors, and explanatory and comforting information should be provided on protection from the epidemic.

- The research was conducted on adolescents from different socio-economic levels. However, research results by socio-economic level were not reported. This can be considered as the limitation of the research. Researchers can design studies to determine the socio-economic level's perceptions of adolescents towards the epidemic.

- Limitations Data in the study were collected on Google form. Due to the pandemic process, when the schools were closed and the quarantine was in progress, the data could not be collected by interviewing adolescents face to face. For this reason, researchers can conduct face-to-face interviews with adolescents and study the effects of the epidemic on adolescents. 
- The research was conducted with adolescents studying at high school level. Researchers can conduct studies to determine the effect of pamdemic on children studying at other levels (such as preschool, primary school, secondary school).

\section{Acknowledgements or Notes}

The study was approved by the Erzincan Binali Y1ldırım University Humanitarian Research Ethics Committee (Protocol No:04/05, Date: 30/04/2020).

In the research, all the rules in the "Higher Education Institutions Scientific Research and Publication Ethics Directive" were followed, and none of the actions contrary to scientific research and publication ethics took place.

\section{References}

Bedford, J., Enria, D., Giesecke, J., Heymann, D. L., Ihekweazu, C., Kobinger, G., ... \& Ungchusak, K. (2020). COVID-19: towards controlling of a pandemic. The Lancet, 395(10229), 1015-1018.doi:https://doi.org/10.1016/S0140-6736(20)30673-5

Cao, W., Fang, Z., Hou, G., Han, M., Xu, X., Dong, J., \& Zheng, J. (2020). The psychological impact of the COVID-19 epidemic on college students in China. Psychiatry research, 112934. doi: https://doi.org/10.1016/j.psychres.2020.112934

Christ, G. H.,\& Christ, A. E. (2006). Current approaches to helping children cope with a parent's terminal illness. CA: A Cancer Journal for Clinicians, 56(4), 197-212. doi:https://doi.org/10.3322/canjclin.56.4.197

Christensen, L. B., Johnson, R. B., Turner, L. A. (2011). Research methods, design, and analysis (11th ed.). Boston, MA: Pearson.

Cullinane, C.,\& Montacute, R. (2020). Research Brief: April 2020: COVID-19 and Social Mobility Impact Brief\# 1: School Shutdown.

Davis, C., Chong, N. K., Oh, J. Y., Baeg, A., Rajasegaran, K., \& Chew, C. S. E. (2020). Caring for children and adolescents with eating disorders in the current COVID-19 pandemic: A Singapore perspective. Journal of Adolescent Health. doi: https://doi.org/10.1016/j.jadohealth.2020.03.037

Dsouza, D. D., Quadros, S., Hyderabadwala, Z. J., \& Mamun, M. A. (2020). Aggregated COVID-19 suicide incidences in India: Fear of COVID-19 infection is the prominent causative factor. doi:10.31234/osf.io/7xa4b

Ekici, G.,\& Akdeniz, H. (2018). Lise öğrencilerinin “ödev” kavramına ilişkin metaforik algilarının incelenmesi [Investigation of metaphorical perceptions of high school students related to the concept of "homework"]Bayburt Eğitim Fakültesi Dergisi, 13(25), 135162. Retrieved from: http://static.dergipark.org.tr/articledownload/4bbd/e47b/c2e6/5b37ad6766b19.pdf?

Gentles, S. J., Charles, C., Ploeg, J., \& McKibbon, K. A. (2015). Sampling in qualitative research: Insights from an overview of the methods literature. The qualitative report, 20(11), 1772-1789. Retrieved from: https://cpb-use1.wpmucdn.com/sites.nova.edu/dist/a/4 /files/ 2016/01/Gentles_Sampling-2016-0116.ppt.pdf 
Golberstein, E., Wen, H., \& Miller, B. F. (2020). Coronavirus disease 2019 (COVID-19) and mental health for children and adolescents. JAMA pediatrics.

Görgülü Arı, A. \& Arslan, K. (2020). Ortaokul öğrencilerinin Covid-19'a yönelik metaforik alg1lar1 [Covid-19 perception in middle school student' mind].Turkish Studies, 15(6), 503524. doi: https://dx.doi.org/10.7827/TurkishStudies.44425

Hawryluck, L., Gold, W. L., Robinson, S., Pogorski, S., Galea, S., \& Styra, R. (2004). SARS control and psychological effects of quarantine, Toronto, Canada. Emerging Infectious Diseases, 10(7), 1206. doi: 10.3201/eid1007.030703

Jiao, W. Y., Wang, L. N., Liu, J., Fang, S. F., Jiao, F. Y., Pettoello-Mantovani, M., \& Somekh, E. (2020). Behavioral and Emotional Disorders in Children during the COVID-19 Epidemic. The Journal of pediatrics. doi: 10.1016/j.jpeds.2020.03.013

Jiloha, R. C. (2020). COVID-19 and Mental Health. Epidemiology International (E-ISSN: 24557048), 5(1), 7-9. doi: https://doi.org/10.24321/2455.7048.202002

Khabbaz, R. F., Moseley, R. R., Steiner, R. J., Levitt, A. M., \& Bell, B. P. (2014). Challenges of infectious diseases in the USA. The Lancet, 384(9937), 53-63. doi: https://doi.org/10.1016/S0140-6736(14)60890-4

Lee, J. (2020). Mental health effects of school closures during COVID-19. The Lancet. Child \& Adolescent Health. doi: 10.1016/S2352-4642(20)30109-7

Liu, J. J., Bao, Y., Huang, X., Shi, J., \& Lu, L. (2020). Mental health considerations for children quarantined because of COVID-19. The Lancet Child \& Adolescent Health, 4(5), 347349.doi:https://doi.org/10.1016/S2352-4642(20)30096-1

Marczyk, G.,\& DeMatteo, D. (2005). Essentials of research design and methodology. John Wiley \& Sons.

Miles, B. M., Huberman, A. M. (1994) Qualitative data analysis: An Expanded Sourcebook. Second Edition. London: Sage.

Qutoshi, S. B. (2018). Phenomenology: A philosophy and method of inquiry. Journal of Education and Educational Development,5(1), 215-222. Retrieved from: https://www.journals.iobmresearch.com/index.php/JoEED/article/view/2154

Pakpour, A. H.,\& Griffiths, M. D. (2020). The fear of COVID-19 and its role in preventive behaviors. Journal of Concurrent Disorders. Epub ahead of print. Retrieved from:

https://concurrentdisorders.ca/2020/04/03/the-fear-ofcovid-19-and-its-role-inpreventivebehaviors/

Perrin, E. C. (2020). Promotion of Mental Health as a Key Element of Pediatric Care. JAMA pediatrics.

Reiner, R. C., Olsen, H. E., Ikeda, C. T., Echko, M. M., Ballestreros, K. E., Manguerra, H., ... \& Strub, B. (2019). Diseases, injuries, and risk factors in child and adolescent health, 1990 to 2017: findings from the Global Burden of Diseases, Injuries, and Risk Factors 2017 Study. JAMA pediatrics, 173(6), e190337-e190337. doi: 10,1001 / jamapediatrics.2019.0337 
Rundle, A. G., Park, Y., Herbstman, J. B., Kinsey, E. W., \& Wang, Y. C. (2020). COVID-19 Related School Closings and Risk of Weight Gain Among Children. Obesity. doi: https://doi.org/10.1002/oby.22813

Saban, A. (2004). Giriş düzeyindeki sınıf öğretmeni adaylarının öğretmen kavramına ilişkin ileri sürdükleri metaforlar. Türk Eğitim Bilimleri Dergisi, 2, 135-155. Retrieved from: http://static.dergipark.org.tr/article-download/8545/4fb1/95a8/imp-JA98KU27EH-0.pdf?

Shaw, S. C. (2020). Hopelessness, helplessness and resilience: The importance of safeguarding our trainees' mental wellbeing during the COVID-19 pandemic. Nurse Education in Practice, 44, 102780. doi: 10.1016/j.nepr.2020.102780

Sprang, G.,\& Silman, M. (2013). Posttraumatic stress disorder in parents and youth after healthrelated disasters. Disaster medicine and public health preparedness, 7(1), 105110.doi: https://doi.org/10.1017/dmp.2013.22

Stein, A., Lehtonen, A., Harvey, A. G., Nicol-Harper, R., \& Craske, M. (2009). The influence of postnatal psychiatric disorder on child development. Psychopathology, 42(1), 11-21. doi: 10.1159/000173699

Şahbudak, B.,\& Emiroğlu, N. I. (2020). Çocuk ve ergende COVID-19 salgını ve duygudurum bozuklukları birlikteliği [COVID-19 pandemic and mood disorders in children and adolescent].Çocuk ve Gençlik Ruh Să̆llğg Dergisi,27(2), 59-63. doi: 10.4274/tjcamh.galenos.2020.55265

Taghizadeh Moghaddam, H., Bahreini, A., Ajilian Abbasi, M., Fazli, F., \& Saeidi, M. (2016). Adolescence Health: the needs, problems and attention. International Journal of Pediatrics, 4(2), 1423-1438. doi:http://eprints.mums.ac.ir/id/eprint/6064

Tut, E., Kıroğlu, K., \& Bayraktar, G. (2018). Suriyeli ve Türk öğrencilerin öğretmen ve okul kavramlarına yönelik metaforik algılarının incelenmesi[An examination of the metaphorical perceptions of Syrian and Turkish students towards the concept of teacher and school]. Journal of International Social Research,11(56), 676-694. doi: http://dx.doi.org/10.17719/jisr.20185639040

Wang, G., Zhang, Y., Zhao, J., Zhang, J., \& Jiang, F. (2020). Mitigate the effects of home confinement on children during the COVID-19 outbreak. The Lancet, 395(10228), 945947.doi:https://doi.org/10.1016/S0140-6736(20)30547-X

Van Lancker, W.,\& Parolin, Z. (2020). COVID-19, school closures, and child poverty: a social crisis in the making. The Lancet Public Health, 5(5), e243-e244. doi:https://doi.org/10.1016/S2215-0366(20)30073-0

Yao, H., Chen, J. H., \& Xu, Y. F. (2020). Patients with mental health disorders in the COVID-19 epidemic. The Lancet Psychiatry,7(4), e21.doi:https://doi.org/10.1016/S2215$\underline{0366(20) 30090-0}$

Yıldırım, A.,\& Şimşek, H. (2016). Sosyal bilimlerde nitel araştırma yöntemleri (10. bs.). Ankara: Seçkin Yayıncılık. 